\title{
International Legal CoOperation AND The Principle of JURISDICTION: LESSONS FROM FAMILY LAW
}

\author{
Guilherme Calmon Nogueira da Gama ${ }^{1}$ \\ Universidade Estácio de Sá, Brazil
}

\begin{abstract}
This extended abstract aims to point out the need to conceptualize the principle of jurisdiction and to identify its main controversies in the field of international legal cooperation. Issues related to the notion of public order, private autonomy, rights and procedural guarantees, among others, have proved to be fundamental for a more adequate understanding of the subject of jurisdiction from the perspective of international legal cooperation. The specific study will address Hague Convention's approach to the civil aspects of international child abduction related to the theme "right of custody" under the Family Law.
\end{abstract}

Keywords: International Legal Cooperation, jurisdiction, family law.

Since March 2016, the Brazilian Code of Civil Procedure (CPC) regulates, in further detail, the issues of the limits of Brazilian national jurisdiction and instruments of international legal cooperation involving the justice system. Issues related to Brazilian jurisdiction, existence (or absence) of disputes, ratification of foreign judicial sentences, choice of court agreement in international contracts, direct assistance, rogatory letter, were dealt with in the rules contained in articles 21 to 41 of the CPC.

Brazilian law experiences a transformation in the culture that involves transnational relations. The search for greater agility, effectiveness and speed in resolving conflicts, encouraging foreign investments in the country, encouraging a consensual solution to conflicts - through conciliation, mediation, negotiation - are aspects that demonstrate a new stage inaugurated in the Brazilian legal system in international relations.

The greater agility in the procedural acts - including judicial ones - requires the presence of special rules that favor the fulfillment of the solutions that may be given to conflicts. There is a duty for national States to cooperate with each other to ensure the full functioning of justice systems and, ultimately, to ensure the smooth functioning of societies and national governments.

In light of the principle of jurisdictional unity, a monopoly of jurisdictional function has been attributed to judicial authorities in Brazil, but it is currently being questioned due to

\footnotetext{
${ }^{1}$ Permanent Professor of the UNESA Stricto Sensu Postgraduate Program in Law. gcalmon@trf2.jus.br
} 
the various problems related to the effective solution of conflicts of interest. In the context of the so-called mass disputes, which are verified with increasing frequency, it is essential to reflect on the judicial procedures that were expressly adopted in the Brazilian procedural system, especially regarding the notion of effectiveness of the solutions.

As an example, the Hague Convention on international access to justice, approved in 1980 , seeks to establish a similarity between the application of the rules on legal assistance to non-domiciled persons in Brazilian territory, such as exemption from the deposit for filing a lawsuit (art. 14 of the said Convention). In the Brazilian case, there was an "intense interaction between the Ministry of Justice, which acts as a central authority, and the Public Defender's Office, which provides legal assistance to those in need". ${ }^{2}$

Current times impose a review of the concept of jurisdiction, which has traditionally been linked to the monopoly of the national State and to the concrete will of the law as an "attribute of sovereignty". ${ }^{3}$ There is a tendency to increasingly value private autonomy in the search for the solution of controversies in the environment of the Democratic State.

In the civil and business (or commercial) sphere, it is recognized that contractors can elect a certain national state jurisdiction to resolve future conflicts that may arise from the contractual relationship. This is a clause for the choice of court or an extended forum agreement.

In the Brazilian legal system, some questions arose: i) may the court elected by the contractors not recognize and, therefore, not judge the judicial claims? ii) should a court decline the case in favor of another elected by the contractors (now litigants)? iii) should any sentence issued by the elected court be recognized in the derogated court? ${ }^{4}$

Such issues are more important according to the greater or lesser sensitivity of national States in terms of recognition of private autonomy in the submission of a dispute resolution to a given jurisdiction. There are two characteristics related to international legal cooperation that are associated with the notions of multiculturalism and the search for uniformity in the understanding and recognition of certain legal phenomena and institutes.

\footnotetext{
2 NÁdia de Araújo, A Conferência da Haia de Direito Internacional Privado e SEus impactos na sociedade - 125 ANOS (1893-2018) 124 (2018).

${ }^{3}$ Valesca Raizer Borges Moschen \& Hermes Zaneti Júnior, Temas controversos do Direito Processual Civil internacional, Direito InTERnACIONAL PRIVAdo 357 (André de Carvalho Ramos org.) (2016).

${ }^{4} I d$. at 358.
} 
The court election clause, in international contracts, constitutes an act of provision according to which the contractors stipulate that only judicial proceedings can be initiated in the jurisdiction chosen by common agreement. However, there are limits to its stipulation, such as the availability of the substantive right involved in the issue, respect for the balance between the parties (and the "parity of arms") and the preservation of observance of the fundamental rights and guarantees of the process in the Democratic State ${ }^{5}$.

At the Hague Conference on Private International Law, the Convention on Choice of Court Agreements was approved in 2005, the main objective of the said Convention being to establish instruments of international legal cooperation in order to allow greater flexibility, effectiveness and security to contracts in civil and commercial matters, based on private autonomy. One of the main aspects of the aforementioned Convention represents the duty of national States to judge the processes based on the clause of choice of court (article 5,2) and, thus, to rule out the possibility of using the "forum non conviniens" doctrine.

There are also rules that establish the obligation of national States to recognize and enforce judgments and decisions handed down in the exercise of the jurisdiction of the State elected by the contractors (article 8). Such rules are in line with the Brazilian CPC rules, especially article 25 which provides for the derogation of Brazilian jurisdiction when the parties have agreed another court, either in the instrument of the international contract or by a separate act of the contract.

Apart from international contracts, private international law has also been concerned with the issue of jurisdiction over certain sensitive matters, such as the Hague Convention on civil aspects of international child abduction. This Convention provides for the impossibility of the requested State not making a decision on the child's custody right until the issue of the child's return (or not) to the requesting State has been resolved (article 16 of the Convention).

Still on issues related to international child abduction, there is the recommendation of the Hague Conference to obtain "mirror decisions" that may reflect the same content as was decided in the Requested State also in the Requesting State, as for example in the regulation of the visiting rights in favor of one of the child's parents.

The research to be developed points to the need to conceptualize the principle of jurisdiction and to identify the main controversies surrounding the respective theme in the field

\footnotetext{
${ }^{5}$ Moschen \& Zaneti Júnior, supra note 3, at 359.
} 
of international legal cooperation. Issues related to the notion of public order, private autonomy, rights and procedural guarantees, among others, have proved to be fundamental for a more adequate understanding of the subject of jurisdiction from the perspective of international legal cooperation.

\section{REFERENCE LIST}

N. de Araújo, A Conferência da Haia de Direito Internacional Privado e seus IMPACTOS NA SOCIEDADE - 125 ANOS (1893-2018) (2018).

V. R. Borges Moschen \& H. Zaneti Júnior, Temas controversos do Direito Processual Civil internacional, DIREITO INTERNACIONAL PRIVADO (Andre de Carvalho Ramos org.) 357-372 (2016). 